\title{
Effect of grinding process on the level of leachability of the contaminants from the fly ashes from combustion of biomass
}

\author{
Aleksandra Pawlukia \\ ${ }^{1}$ AGH University of Science and Technology, Faculty of Mining and Geoengineering , Cracow, Poland
}

\begin{abstract}
The most commonly used renewable energy source in Polish energy production companies is solid biomass which is used both as a separate fuel or as a component co-incinerated together with (mostly) hard coal. During its incineration the biomass generates by-products with diverse and variable physicochemical properties. The most of the waste from production of electricity and/or heat are fly ashes. The fly ashes from combustion of biomass are a particular kind of waste distinguished by high level of leaching of contaminants and variable chemical composition. The by-products from combustion can only be used in production when their physicochemical properties meet specific parameters. This article presents results of research on leachability of chemical pollutants from dry ashes of combustion or co-combustion of biomass. The study of the impact of grinding of ashes on the level of their leachability was also conducted. Ashes from combustion of biomass as well as their mixture with fluidized ash from combustion of charcoal were submitted to grinding process. Afterwards level of leachability was measured on them to determine prospect of utility in mining technologies.
\end{abstract}

\section{Introduction}

Solid biomass is the third biggest (after solar and wind energy) renewable energy source in the world $[8,3]$. It is the most commonly used renewable energy source in Polish energy production. Biomass is used both as a separate fuel as well as a component co-incinerated together with (mostly) hard coal.

Likewise combustion of hard coal and lignite, combustion of biomass generates solid by-products, mainly ashes. As Poland already employs special boilers for combustion of biomass as a single fuel source, a "new generation of by-products" emerges - the fly ashes from combustion of biomass [7].

The by-products from combustion of biomass characterize with diverse and variable physicochemical properties. The most of the waste from production of electricity and/or heat are fly ashes. The fly ashes from combustion of biomass (10 01 03) are a particular kind of waste distinguished by high level of leachability of contaminants and variable chemical composition. The level of leachability of contaminants determines the use of fly ashes in the industry [12].

Fly ashes from combustion of conventional energy sources are commonly used in many branches of industry. Generally in production of building materials and mining technologies. Ashes from combustion of biomass are also utilized in the industry, for example production of building materials.

The side-products from incineration can only be used in production when their physicochemical properties meet specific parameters. One of the important indicators is level of leaching of contaminants. Unexceeding of required levels of leaching of chemical substances can decide on way of utilization.

Taking the above into consideration it is only reasonable to analyze the leachability of side-products from biomass combustion in different kinds of boilers and the possibilities of limitation which could allow to determine potential usage of these kinds of ashes.

This article presents results of research on leachability of chemical contaminants from dry ashes of combustion or co-combustion of biomass. The study of the impact of grinding on the level of leachability was also conducted. Fly ashes from combustion of biomass as well as their mixture with fluidized ash from combustion of hard coal were submitted to grinding process. Afterwards level of leachability was measured on them to determine initial prospect of their utilization in mining technologies. The results of the research on leachability of ashes were compared to PN-G-11011 Mining Norm Materials For Backfilling And Caulking Of Cavings Requirements And Tests because fly ashes are commonly used as suspended matter in underground mining [6].

\section{Materials used in the research}

For this research I used fly ashes from combustion of solid biomass in power production company which were included by the decree of the Ministry of the Environment from 9th of December 2014 for Catalog of Wastes (Dz.U. 2014, poz. 1923), to group 10

\footnotetext{
arzywa@agh.edu.pl
} 
- the by-products from thermal processes, subgroup 10 01 - by-products from power companies and other enterprises of production of energy by combustion of fuels (excluding group 19).It was also two kinds of by-products from combustion in fluidized boilers and co-combustion in pulverized-fuel boilers.

The research was conducted on two kinds of fly ashes:

a) From combustion of biomass $\left(\begin{array}{lll}10 & 01 & 03\end{array}\right)$ :

- in fluidized boiler with atmospheric circulation (Fig.1a) - SW

- in fluidized boiler with circulating fluidized bed (Fig.1b) - K9,

- in fluidized boiler with bubbling fluidized bed (Fig.1c) - T.

b) From co-incinerated biomass with hard coal (10 001 17):

- In pulverized-fuel boiler (Fig. 1d) - 2MP1 .

In the research I also used the ash with code 100182 from combustion of hard coal in fluidized boilers - PF (Fig. 1e), with a low level of leachability of contaminants. This ash was grinded with dry ashes from combustion and co-combustion of biomass in ratio $1: 1$.
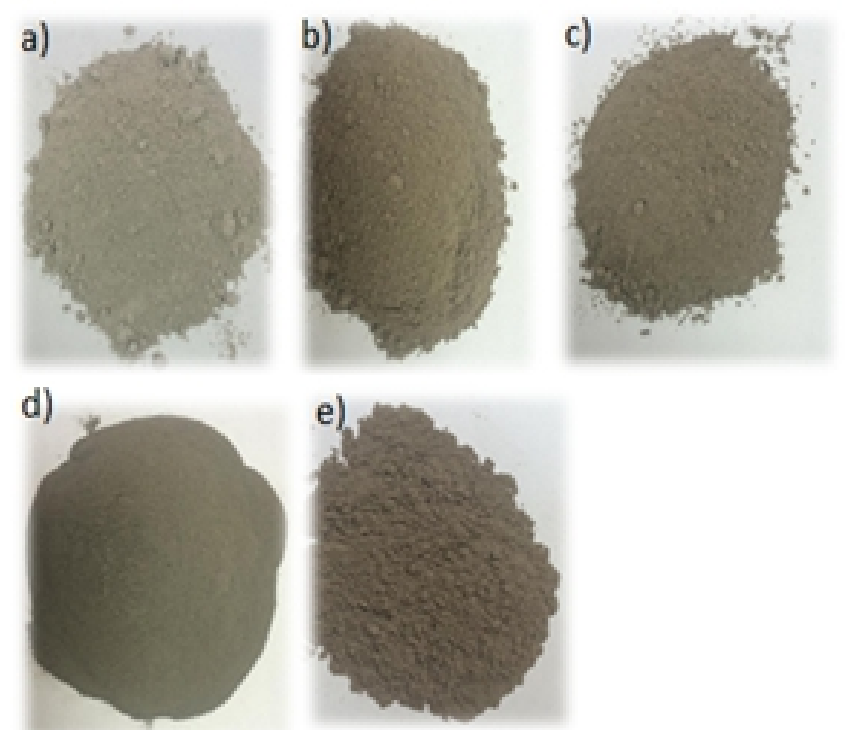

Figure 1. The ashes used in the research

Comparing the fly ashes from combustion of biomass with the ashes from combustion of hard coal, it appears that the qualitative composition of chemical elements of both ashes is very similar. The differences turn up in quantity of particular elements and the compounds in the composition of ashes. In the fly ashes from combustion and co-combustion of biomass the levels of compounds like $\mathrm{CaO}, \mathrm{MgO}, \mathrm{Na}_{2} \mathrm{O}, \mathrm{K}_{2} \mathrm{O}, \mathrm{P}_{2} \mathrm{O}_{5}$ are significantly higher whereas levels of $\mathrm{SiO}_{2}, \mathrm{Al}_{2} \mathrm{O}_{3}, \mathrm{TiO}_{2}$ are lower compared to ashes from combustion of hard coal $[4,12]$.

Fly ashes from combustion of biomass characterize by high level of leachability of ions of potassium, chromium, sulfates and chlorides in a scale greatly higher than the levels of ashes from combustion of hard coal in conventional and fluidized boilers. The high level of leachability of contaminants from fly ashes from combustion of biomass depends mostly on the type of fuel, so it can be easily limited by mixing them with ashes from combustion of coal in conventional and fluidized boilers [9].

High content of calcium, alkalis, phosphorus as well as variable and often high content of chlorine can cause intensive corrosion and increase in presence of aggressive sediments in the boiler during the combustion $[1,5]$.

Table 1. The chemical composition of the ashes used in the research, in \% [10]

\begin{tabular}{|c|c|c|c|c|c|}
\hline \multirow{2}{*}{ Compound } & \multicolumn{5}{|c|}{ Type of as h } \\
\cline { 2 - 6 } & $\mathrm{SW}$ & $\mathrm{K} 9$ & $\mathrm{~T}$ & $2 \mathrm{MP} 1$ & $\mathrm{PF}$ \\
\hline $\mathrm{SiO}_{2}$ & 28,86 & 62,43 & 34,06 & 52,79 & 51,20 \\
\hline $\mathrm{Al}_{2} \mathrm{O}_{3}$ & 2,17 & 6,21 & 4,57 & 22,80 & 11,27 \\
\hline $\mathrm{Fe}_{2} \mathrm{O}_{3}$ & 1,84 & 2,53 & 2,90 & 6,25 & 5,63 \\
\hline $\mathrm{CaO}$ & 23,05 & 8,63 & 21,13 & 5,17 & 4,25 \\
\hline $\mathrm{MgO}$ & 6,82 & 3,42 & 5,64 & 2,85 & 3,03 \\
\hline $\mathrm{Cl}$ & 1,82 & 0,45 & 1,19 & 0,01 & b.d. \\
\hline $\mathrm{SO}_{3}$ & 7,12 & 3,08 & 9,97 & 0,41 & 0,76 \\
\hline $\mathrm{Na}_{2} \mathrm{O}$ & 0,40 & 0,46 & 0,61 & 1,18 & 0,90 \\
\hline $\mathrm{K}_{2} \mathrm{O}$ & 18,11 & 3,73 & 13,65 & 3,06 & 1,59 \\
\hline $\begin{array}{c}\text { Losses of } \\
\text { calcination }\end{array}$ & 4,47 & 4,33 & 6,71 & 4,65 & 0,11 \\
\hline
\end{tabular}

All examined ashes had a high content of $\mathrm{SiO}_{2}$. Fly ashes from combustion of biomass showed high levels of $\mathrm{CaO}, \mathrm{K}_{2} \mathrm{O}$ and $\mathrm{CaO}$. It is worth mentioning that the fly ashes had notable levels of $\mathrm{SO}_{3}$ while in ashes from co-combustion this level was insignificant. On the other hand, in the composition of ashes from co-combustion with hard coal the high content of $\mathrm{Al}_{2} \mathrm{O}_{3}$ and $\mathrm{Fe}_{2} \mathrm{O}_{3}$ was observed. And Tests because fly ashes are commonly used as suspended matter in underground mining [6].

\section{Analysis of the leachability of contaminants}

The research was conducted according to the Norm PN-G- 11011: 1998 Mining - Materials For Backfilling And Caulking Of Cavings - Requirements And Tests.

Subjected for the analysis where the fly ashes from combustion and co-combustion of biomass ( SW, K9, T, 2MP1) (Tab. 2), the same ashes after the process of grinding and their mixtures with ash from combustion of hard coal 100182 (PF) in ration 1:1 (Tab. 3).

The results of the research on leachability of ashes were compared with the requirements of the Norm PN-G11011 Mining Norm - Materials For Backfilling And Caulking Of Cavings - Requirements And Tests (Tab. 4). 
Analysed samples of each type of fly ash showed similar $\mathrm{pH}$ reaction, between 11,92 and 12,79.

The fly ashes from both combustion and co-combustion characterized by significant leachability of chromium, cadmium, lead, copper, and mercury in comparison to PF ashes (Tab. 2 and 3).

The leachability of sulfate and chloride ions from the fly ashes from combustion and co-combustion of biomass was also a couple or a dozen times higher than in case of the ashes of combustion of hard coal.

Table 2. The leachability of chemical contaminants from the researched ashes, $\mathrm{mg} / \mathrm{dm}^{3}[9-10]$

\begin{tabular}{|c|c|c|c|c|c|}
\hline \multirow{2}{*}{ Le achability } & \multicolumn{5}{|c|}{ Dry ash } \\
\cline { 2 - 6 } & $\mathrm{SW}$ & $\mathrm{K} 9$ & $\mathrm{~T}$ & $2 \mathrm{MP} 1$ & $\mathrm{PF}$ \\
\hline $\mathrm{pH}$ & 12,79 & 12,25 & 12,46 & 11,96 & 11,92 \\
\hline & & & & & \\
\hline $\mathrm{Cl}-$ & 1449,02 & 445,64 & 658,34 & 150,32 & 109,20 \\
\hline $\mathrm{K}$ & 9446,09 & 604,31 & 3160,99 & 223,19 & 28,21 \\
\hline $\mathrm{Na}$ & 82,91 & 25,36 & 67,36 & 26,00 & 32,62 \\
\hline $\mathrm{Cd}$ & 0,13 & 0,34 & 0,07 & 0,45 & 0,01 \\
\hline $\mathrm{Cu}$ & 164,24 & 446,99 & 201,31 & 44,16 & 0,01 \\
\hline $\mathrm{Cr}$ & 1,63 & 1,16 & 1,42 & 1,55 & 0,02 \\
\hline $\mathrm{Hg}$ & 0,37 & 0,14 & 0,04 & 1,00 & 0,02 \\
\hline $\mathrm{SO}_{4}{ }^{2-}$ & 5745,81 & 1436,94 & 4779,65 & 790,51 & 670,80 \\
\hline
\end{tabular}

Table 3. The leachability of chemical contaminants from the researched ashes after grinding separately, $\mathrm{mg} / \mathrm{dm}^{3}$

\begin{tabular}{|c|c|c|c|c|}
\hline \multirow{2}{*}{ Leachability } & \multicolumn{4}{|c|}{ Grinded as hes } \\
\cline { 2 - 5 } & $\mathrm{SW}$ & $\mathrm{K} 9$ & $\mathrm{~T}$ & $2 \mathrm{MP} 1$ \\
\hline $\mathrm{Cl}-$ & 1329,3750 & 428,3542 & 658,0875 & 138,2550 \\
\hline $\mathrm{K}$ & 7677,4288 & 525,1561 & 3160,9101 & 199,5052 \\
\hline $\mathrm{Na}$ & 71,2992 & 23,2680 & 60,3095 & 25,6060 \\
\hline $\mathrm{Cd}$ & 0,1200 & 0,1390 & 0,0660 & 0,3070 \\
\hline $\mathrm{Cu}$ & 132,1490 & 287,6190 & 156,3770 & 37,7210 \\
\hline $\mathrm{Cr}$ & 1,2630 & 0,8770 & 0,4870 & 0,8710 \\
\hline $\mathrm{Hg}$ & 0,5150 & $<$ & 0,0400 & 0,0880 \\
\hline $\mathrm{SO}_{4}{ }^{2-}$ & 3391,0427 & 1293,5499 & 4906,7672 & 767,7367 \\
\hline
\end{tabular}

The high leachability of contaminants like potassium, chlorides and sulphates confirms the results of researches conducted by other authors [2,9-11].
Achieved values of leachability of fly ashes from combustion of biomass greatly exceeded the requirements of the Norm PN-G-11011 Mining Norm - Materials For Backfilling And Caulking Of Cavings - Requirements And Test. The process of grinding together with PF ashes caused the decrease in leachability to below $1000 \mathrm{mg} / \mathrm{dm}^{3}$ only in case of chlorides.

The conducted research reviled very high leachability of ions of potassium from fly ashes from combustion of biomass $\left(9446,0938 \mathrm{mg} / \mathrm{dm}^{3}\right)$, co-combustion $(223,1981$ $\mathrm{mg} / \mathrm{dm}^{3}$ ) and combustion of hard coal in fluidized boilers (10 0182$)\left(28,21 \mathrm{mg} / \mathrm{dm}^{3}\right)$.

Table 4. The leachability of chemical contaminants from the researched ashes after grinding with ash PF (10 01 82), mg/dm ${ }^{3}$

\begin{tabular}{|c|c|c|c|c|}
\hline \multirow{2}{*}{ Leachability } & \multicolumn{4}{|c|}{ Ashes grinded with as h PF (10 01 82) } \\
\hline & $\mathrm{SW}$ & $\mathrm{K} 9$ & $\mathrm{~T}$ & $2 \mathrm{MP} 1$ \\
\hline $\mathrm{Cl}-$ & 635,1458 & 194,9750 & 464,3950 & 56,7200 \\
\hline $\mathrm{K}$ & 3028,0372 & 240,1898 & 2278,4060 & 125,8354 \\
\hline $\mathrm{Na}$ & 43,1195 & 17,6513 & 47,8768 & 26,2035 \\
\hline $\mathrm{Cd}$ & 0,1280 & 0,3070 & 0,0760 & 0,4240 \\
\hline $\mathrm{Cu}$ & 70,4970 & 163,9590 & 115,3860 & 41,0440 \\
\hline $\mathrm{Cr}$ & 0,5940 & 0,9520 & 0,5740 & 1,1440 \\
\hline $\mathrm{Hg}$ & 0,2680 & 0,0950 & 0,0400 & 0,0310 \\
\hline $\mathrm{SO}_{4}{ }^{2-}$ & 3135,1305 & 601,5172 & 2345,9992 & 287,1812 \\
\hline
\end{tabular}

Table 5. The levels of leachability permitted by the Norm PNG-1101, $\mathrm{mg} / \mathrm{dm}^{3}$

\begin{tabular}{|c|c|}
\hline $\begin{array}{c}\text { Type of che mical } \\
\text { contaminant }\end{array}$ & $\begin{array}{c}\text { Permitted levels of } \\
\text { leachability by Norm PN- } \\
\text { G-11011 }\end{array}$ \\
\hline Elements & 2,0 \\
\hline zink $(\mathrm{Zn})$ & 0,5 \\
\hline copper $(\mathrm{Cu})$ & 0,5 \\
\hline lead $(\mathrm{Pb})$ & 0,2 \\
\hline arsenic $(\mathrm{As})$ & 0,02 \\
\hline mercury $(\mathrm{Hg})$ & 0,1 \\
\hline cadmium $(\mathrm{Cd})$ & 0,5 \\
\hline chromium $(\mathrm{Cr})$ & 1000,0 \\
\hline chlorides $(\mathrm{Cl}-)$ & 500,0 \\
\hline sulphates $(\mathrm{SO} 42-)$ & \\
\hline
\end{tabular}

Grinding of the fly ashes and the mixture of ashes SW, K9, T and 2MP1 with PF ash allowed the decrease of leachability of potassium, sodium, copper, chromium, sulphates and chlorides but not to a degree that would 
be compliant with the Norm (Tab. 5). The process of grinding of fly ashes alone didn't give big impact on the level of leachability, more satisfactory results of reduction of leachability were shown during grinding of mixture of ashes from combustion and co-combustion of biomass.

\section{Conclusion}

The examined fly ashes from combustion and co-combustion of biomass differ from ashes from combustion of hard coal as to the chemical composition and leachability.

The contaminants for which the leachability was significant was potassium, sodium, chlorides and sulphates. The levels of leachability for these contaminants greatly exceed the values of ashes from combustion of hard coal.

The process of grinding of fly ashes and grinding them together with ashes from combustion of hard coal with the low level of leachability decreased the amount of leaching components. But, despite the reduction, values of leachability for most of the contaminants highly exceed the requirements of the Norm to PN-G-11011 Mining Norm - Materials For Backfilling And Caulking Of Cavings - Requirements And Tests.

The research were conducted as a part of deans grant 15.11.100.912.

\section{References}

1. T. Hardy, W. Kordylewski, K. Mościcki, Zagrożenie korozja chlorkowa $w$ wyniku spalania $i$ wspótspalania biomasy w kotłach, (Instytut Techniki Cieplnej i Mechaniki Płynów Politechniki Wrocławskiej 2010)

2. A. Jaworek, T. Czech, A. Sobczyk, A. Krupa, J. of Electrost. 71, 165-175 (2013)

3. M. Kosior- Kazberuk, Nowe dodatki mineralne do betonu, Budownictwo i inżynieria środowiska, (ISSN: 2081-3279, 2011)

4. J. Małolepszy, E. Tkaczewska, Wpływ popiołów lotnych ze wspótspalania węgla kamiennego $i$ biomasy na proces hydratacji $i$ wtaściwości cementu, (Materiały konferencji Dni Betonu, Wisła 2006)

5. W. Mokrosz, Migracja związów chloru z biomasy w procesie spalania oraz ich wptywu na procesy korozyjne i eksploatacyjne kotłów, (MOKROSZ Sp. z o.o, Politechnika Śląska 2014)

6. PN G-11011:1998 Mining - Materials for Backfilling and Caulking of Cavings - Requirements and Tests

7. J. Poluszyńska, Możliwości zastosowania popiołów ze spalania biomasy w gospodarowaniu osadami ściekowymi, Prace Instytutu Ceramiki i Materiałów Budowlanych 13 (2013)

8. Raport GUS, Energia ze źródeł odnawialnych, Warszawa (2014)

9. A. Uliasz-Bocheńczyk, A. Pawluk, A. Sierka, Gosp. Sur. Min. - Min. Res. Manag. 31(3), 145-156 (2015)
10. A. Uliasz-Bocheńczyk, A. Pawluk, Min. Res. Manag. (2016) [to be published]

11. S. Vassilev, D. Baxter, L. Andersen, C. Vassileva, Fuel 105, 40-76 (2013a)

12. S. Vassilev, D. Baxter, L. Andersen, C. Vassileva, Fuel 105, 19-39 (2013b) 